\title{
Impact of ISO9001 Certification on the Beverage Company's Performance: A Case Study of Brewery Companies in Ethiopia
}

\author{
Gemechu Getahun Amente (MSc.) \\ Ministry of Peace-Ethiopia \\ Equitable Development and Capacity Building Expert, P.O.Box 5608 Addis Ababa
}

\begin{abstract}
This study tries to shade light on the effect of ISO9001 on Performance of Brewery companies in Ethiopia. It empirically analyzes the impact of ISO9001 on the performance of brewery company's proxied by profit of companies during the sample period of 2002-2015.The sample consists three brewery companies namely: BGIEthiopia, Metha-Abo and Dashen brewery companies. The methodology is based on the Fixed effect model estimator proposed for dynamic panel data, which is strong in the presence of endogenous covariates, allowing for individual companies fixed effects, heteroskedasticity and autocorrelation. Based on our findings, out of the four independent variables average revenue and dummy of ISO9001 are positive and significant effect on companies profit i.e an increase (decrease) in average revenue of companies results in a 5.517 percent increase (decrease) in the company's profit. The result indicates that ISO9001 certification does have a strong significant positive impact on brewery companies performance. As the result revealed a company's profit increases by $1.052 \%$ due to ISO9001 certification. The other two explanatory variables average cost and natural logarithm of total sale become statistically insignificant. In sum, the result of the study indicates that Having ISO9001 certification improves the profitability of the brewery companies. This finding seems to agree with the study done by Dejene Tulu (2011) on five brewery companies in Ethiopia and other scholars like Sharma(2005),Pinar(2001) and Singles et al.(2000).
\end{abstract}

Keywords: ISO9001, Brewery companies, performance, ,fixed-effect model.

DOI: $10.7176 /$ IEL/10-1-02

Publication date: January $31^{\text {st }} 2020$

\section{Introduction}

ISO certification stands for certain minimum quality standards that organizations should meet and is said to assure a consistent quality of products, services and processes. The introduction in 1987 of the first international quality assurance standards the ISO 9000 series- was acknowledged importantly in the business world. An ISO 9000 certification is an internationally recognized guarantee that a firm can deliver what it promises, consistently. The ISO 9000 series certification is important to organization seeking to interact internationally. It is also equally important for organizations seeking to perform well in their respective industry.

In case of Ethiopian context, many manufacturers are currently claiming that they have acquired ISO certificates that helped them to perform well in their respective industry. Some of these companies are currently interacting with their customers internationally while the remaining is still in their domestic markets. To this point, the organization should have the system that can assure their products and services are produced as per the requirements. On the other hand, companies seek to gain ISO certification because they think that it can improve their overall business performance. But, the question here is whether ISO certification can impact their performance or not. With this main question, our paper has investigated the impact of ISO certification on the company's performance. For this purpose from the beverage industry, brewery companies in Ethiopia are selected for the study purpose.

The companies were established at different time frame; however, they all have an ISO certificate. Each company are certified for ISO 9001 quality management system. These companies are operated at least for nine years and above. Therefore it is rational to study for their performance based on the available data.

The earlier quality standard lies in the fact that they mainly focused on quality control systems when compared to the current ISO situations (Tummala and Tang 1996) as cited in Dejene,T. (2011). ISO is based on the notion that specific minimum characteristics of quality systems can be standardized, which can give mutual benefits for organizations and their suppliers because each of them knows that they both meet certain requirements concerning quality system. But, ISO do not specify the level of product or service quality rather they specify a set of quality assurance system that must be in place (Finch 2003). Moreover, these procedures describe how operations in an organization must be conducted.

ISO certification does have certain benefits to a given organization. These could be external to the organization or internal to this organization. The internal benefits are related to the process and structure of the organization like improvement in productivity, improvement in efficiency, reduction in cost and waste, better management control and others. Those benefits external to the organizations are: competitive advantage, increase in sale and market share, possible chance of getting into new market, good customer relation and identifying 
potential customers, increased customer satisfaction and the like. Although ISO certification provides both internal and external benefit to a given organization, it says nothing about the performance of those organizations (Singles et al. 2000). There is also an inadequate study on such area that was investigated whether ISO certification increases the performance of a given organization or not. In this paper, the impact of ISO certification on the performance of an organization was investigated

Besides the benefits of ISO certification, there are also certain disadvantages associated with gaining the certificate. Some of the disadvantages are extra cost of obtaining the certificate, increase in paper work load, and no attention for development of personnel. An application of ISO 9001 certificate experience of companies advocates yield benefits to the firm. However, whether ISO 9000 certification is associated with more objective measures of company's performance or not is remained under investigational issue. According to Sharma (2005) if ISO 9000 certification is not positively associated with financial performance, it may possibly lose reliability and be considered as another management obsession. It is, therefore, believable that the self-rated benefits are a self-fulfilling prediction.

This study is designed to identify the problems related with ISO certification and its impact on companies performance by relating the element used to measure the organizations performance, by considering three brewery companies in Ethiopia namely ,BGI Ethiopia, Dashen brewery share company, and Meta abo brewery companies . Therefore, the study finding aimed to contribute literature to this less explored, but very important issue. Also it is important for companies in identifying the relationship between quality management system and success or failure of their business and to enables them to follow suitable policy.

The remnants of the paper is organized as follows: section two comprises a literature review. In section three, the methodological framework of the study is presented, while the empirical results are discussed in section four. Finally, section five concludes the paper.

\section{Literature Review}

This section is in two parts, a theoretical review and a review of empirical literature. These are discussed in roll.

\subsection{Theoretical Literature}

Johnson (1993) acknowledged that the facility with well-designed and well-executed quality system has a process which tends to be change direction, responsive to customer needs, highly reactive, well-organized and positioned at the leading perimeter of its market place. he's idea explains the greatest importance of ISO certification on performance of an organization. It is argued that organizations with ISO certification have better performance than companies which did not get the certificate. But, still there are other organizations which can compete with those certified companies in terms of the overall performance actions. This tells us there is no clear investigation as to how ISO 9001 certification can have an impact on the performance of an organization. According to Harris et al. (1969) the significance of a quality system, depends mostly on how well people do their job. People are accountable for the achievement of the system and play the major role in the function it act upon.

The ISO 9000 Quality guarantee standard was first initiated to surmount trade barriers. Manufacturers saw this as an opportunity to open doors for global business. Though, the main focus of the 1987 and 1994 standards was on external issues such as customers. In majority of cases, the implementation of these standards conveyed about little or no enrichment internally. Padmadinata (2007) indicated that based on customer need, ISO 9001 standards is provided to take its control to meet up with the challenges of the new and constantly changing economy (cited in Dejene, T. 2011).

For Padmadinata (2007) moreover quality management system standard, there is standard particularly for enterprise which produce food or medicine which is Hazard Analysis and Critical Control Point (HACCP). HACCP is a methodical approach to identifying and controlling hazards (i.e. microbiological, chemical or physical) that could pose a risk to the preparation of in safe hands food. It involves identifying what can go incorrect and scheduling to prevent it. In simple terms, to control the security of constituent and supplies coming into a food business and what is done with them subsequently.

A well-executed management system such as one using the ISO 9001:2008 worldwide standard principles dealing with quality management systems, the HACCP standard, and the ISO 14001:2004 environmental management standard, will minimize happening of product-in-process being amended or discarded and finished product being fragmented. This negligible occurrence affects the beverage companies to perform well when they execute such systems. In broad-spectrum, the food safety management system is needed for the companies that affianced in such businesses. Thus, beverage companies, including brewery companies, ought to obey with the international quality standards that certify their products are safe for human use. As the companies are operating in harmony with this standard their customers consume that product.

\subsection{Empirical Literature Review}

The review of past studies performed to identify the impact of ISO certification on the performance of companies 
were presented below.

Most researchers describe that the impact of ISO 9000 on financial performance is a potential sources of debate. A study conducted by Van Der Wiele et al. (2000) substantiates that there is no clear relationship between having ISO 9001 series certificate and the financial performance of an organization. This is mainly due to the reason that ISO 9001 spotlights only on how organizations trim down their costs through minimizing the inspection time, detecting the quality problem early at the production level and the time spent for call backs. ISO also requires the tasks to be conducted as per the stated procedures. However, in general, ISO certified companies have more access to new markets and can control the on hand markets which in turn can improve their financial performance. These improvements could be described by the common financial pointers as return on assets (ROA) and return on sales (ROS).

Analysis of Terlaak and King (2006) recommended that facilities that are ISO certified have a better increase in production volume subsequent to certification than non-certified facilities. Gotzamani and Tsiotras (2002) reported that ISO certification had enhanced the companies quality of products and services as a final goal and improved their internal processes.

Singles et al (2000) described that organizations that are involved in quality management out of an internal inspiration, such as improving their organizational arrangement, improvement of their competitive situation, improvement of their running and trading results, etc., profited most in terms of performance outcomes. He also stated that ISO 9001 standards help to guarantee that organizations follow definite well documented procedures in making of their products or services, and nothing more. Firms are motivated to apply ISO 9001 for quite a lot of reasons. The main reason for companies to implement the standard has been pressure or demands from customers; the improvements certification makes to the company image is the also the most important reason why companies obtain certification.

Moreover, the motivation for ISO 9001 implementation is often claimed to be a significant factor for business achievement which could be external reasons such as, marketing advantages, customer expectation and competitive pressures, instead of internal reasons such as improving the quality of products and services (Feng et al. 2008).

Jackson and Ashton (1995) described ISO 9001 as worldwide standard for quality assurance, recognized throughout the globe. ISO certification stands for certain minimum quality standards that organizations should congregate, and is said to assure a consistent quality of products, services and processes. ISO 9001 certification and audits allow companies to continuously update and control their quality systems. In particular, the quality managers should be committed to quality; should regularly evaluate the quality system; ensure that quality system is frequently improved; and use the internal quality audits to assist in evaluating the success of the quality system (Cagnazzo et al.2009).

According to Cater et al. (1995) ISO 9001 certification provides a arrangement around which build a program of world class quality. This formal structure has the peculiarity of being verifiable and measurable. This formal system of quality guarantees the improvement of all aspects within the company that make sure the quality of the product or service to the customer.

The benefits of ISO certification emerges from the human resource atmosphere. According to Santos (2002), these benefits are noticeable through an increase in internal efficiency, and an improvement in the work environment. Jackson and Ashton (1995) described that a good system requires such staff involvement at the implementation phase. According to Masternak and Kleiner (1995) ISO 9001 certification has three essential benefits for businesses. First, it is required for health, safety, and environmental products sold in the European Community. Second, more and more customers are requiring ISO 9001 certification as a precondition for doing business. Third, many companies see ISO certification as a way to show their customers how they stand out from their competitors, even if ISO 9001 is not necessary.

Santos and Escanciano (2002) described that companies will accomplish the development of a more enough commercial offer for their customer needs, which implies a marked increase in customer satisfaction and trustworthiness, and greater opportunities appear in the access to new markets as a result of the improvements in the commercial management. And also there is an increase in market participation and the firm acquires a strong image. Moreover, as Cagnazzo et al. (2009) identified, the company that get ISO certification may help them in gaining access to the market and the faster reaction to the market demand.

According to Piskar (2007) Working on the way to a process that will bring TQM and marketing together to deliver a customer focus will require changes in the way that marketing is thought of and organized. Customer satisfaction is a wide concept that includes perceived evaluation of product and service. From the process approach of ISO principles, there is great potential to use it in operational dynamism marketing. The kindness of an effective quality system is the desire to meet customer needs as fully as possible and various mechanisms built into the system help to ensure(Jackson and Ashton ,1995).

Davis (1997) specified that suppliers have found that certification improved their image, improved export possibilities and overall competitiveness, and contributed to their ability to sustain their market position. Terlaak 
and King (2006) indicates that buyers often have difficulties identifying suppliers that provide steady product quality, because the suppliers underlying quality attributes are difficult for buyers to observe. This is because such attributes often are intricate, embedded, and difficult to measure. As a result, some buyers have demanded that their upstream supply partners adopt ISO 9001 to disclose their otherwise difficult to observe characteristics.

Firms are moving toward ISO 9001 registration because of competitive coercion. At this time, most of the pressure is not in the nature of requirements or competitive coercions. Rather, it is commercial pressure arising simply from stiffening international competition and the needs of firms everywhere to differentiate among their suppliers, Johnson (1993). It was also found that good quality control and improved performance quality was related to competitive advantage. An imp-active quality management system will have process manage as an essential activity (Heras et al. 2002). Cagnazzo et al. (2009) added that another factor promoting the ISO 9001 series is the desire to improve internal efficiency by reducing waste and non-value added tasks. The ISO 9001 series is seen as tangible and has meaning and that forces organizations to develop manuals and procedures and improve organizational discipline.

One of the major significant improvements reported as an influential impact coming from the ISO 9000 is related to the improved product or service quality (Brown et al. 1998). Quazi and Padibjo (1998) states that ISO 9001 facilitates the improvement of the product quality as well as the satisfaction of customer's needs. Pinar (2001) added that the ISO 9001 had the most immediate and substantial impact on productivity(efficiency), profitability and cost factors. This might suggest that these were the main factors influencing the belief or perceptions of the firms regarding ISO 9001 success. Corbett (2002) supplemented that firms that decided to seek ISO 9001 maintained their return on asset, while the non-certified firms saw their performance decline over time.

The use of ISO certification is connected with an increase in financial performance that brings benefit to stakeholder, Capistriano et al. (2009). He also stated that the positive impact of ISO 9001 certification on a firm's success is even reinforced in a condition where firms otherwise suffer from reputation problems.

Sharma (2005) provided the substantiation that ISO 9001 certification is associated with improvements in financial performance. His results revealed that ISO 9001 certification does bring benefits to the firm and its stakeholders. Profit margin, growth in sales, and earnings per share are among the significant improvements observed as a result of ISO 9001 certification. However, the impact of ISO 9001 certification was greater on profit margin than on growth in sales which suggests that the improvement in overall performance is attributed largely to improvements in internal business processes.

Moreover, Capistrano (2008) obtained that majority of ISO 9001 certified firms experience less fluctuation in their financial ratios after certification and most firms showed improvements in their leverage ratio. But, the author identified that the financial ratios that are perceived to evidently have more direct impact due to certification operating efficiency and asset use efficiency because of its association with TQM have less significance in the study.

Feng et al. (2008) found that there is a significant positive relationship between ISO certification and operational performance. But, the relation was weak for organizational performance. Kuo et al. (2009) reported that ISO certification does bring a significant improvement on the level of quality performance. The study by $\mathrm{Wu}$ and Liu (2010) identified that ISO certification had a significant impact on internal operating processes of a company. Among the internal processes it improved processes standardization and systemization.

Piskar (2007) identified that organizations with systems certification have insignificant impacts on their sales and profitability. The author also reported that ISO certification does have a positive impact on customer satisfaction and they are less loyal to the company as they compare the prices of the company with the competitors. $\mathrm{Wu}$ and Liu (2010) also identified that ISO certification has significantly affected the financial perspective of the company performance of profitability. Their result also showed that ISO certification had a significant impact on improving customer satisfaction. Heras et al (2002) identified that ISO certified firms are enjoyed greater sales growth than those not yet certified. The results of Dimara et al. (2004) indicated that firms obtained their ISO certificate have significantly reduced their cost and showed improvement on their markets.

The study by Sharma (2005) discovered that ISO 9001 certification does bring benefits to the firm and its stakeholders. Profit margin, growth in sales, and earnings per share are among the significant improvements observed as a result of ISO 9001 certification. However, the impact of ISO 9001 certification was greater on profit margin than on growth in sales which suggests that the improvement in overall performance is attributed largely to improvements in internal business processes.

The results of Ragothaman and Korte (1999) indicated that there is an improved documentation system caused by ISO certification. Companies have improved their documentation of products and processes that have an increased efficiency and reduction of the associated costs. As employees were skill training on the implementation of ISO 9001, they contribute for the long term organizational performance. In Ethiopia the study done by Dejene, T (2011) on 5 brewery companies result shows that ISO certification has a significant impact on the company's performance. His finding also indicated that, after ISO certification the companies have acquired improvements on their total sales. 
According to Asian Productivity Organization (2005), all new and promising concepts including HACCP have a greater chance of adoption when the benefits are quantified and presented in monetary terms. A lucid and proactive policy is possibly the most critical factor that separates the success of HACCP from letdown. Additionally, a study by Mulili (2011) provided evidence that ISO certified East African Brewery Limited has constantly improved their profitability over the period between the year 2001 and 2007. Total Quality Management implementation is therefore positively associated with profitability in these companies. The HACCP system which is equally important with ISO 9001 is science-based and systematic, identifies specific hazards and measures for their control to ensure the security of food.

In sum, there are several studies which had been conducted and most of the studies are those in the developed countries, the above literature also shows that there is still a need for further studies and this study will fill the gap in the area particularly to our country, Ethiopia.

\section{Methodology}

This section deals with the method employed to obtain relevant information on ISO9001 certification and financial performance of 3 brewery companies namely BGI Ethiopia, Dashen Brewery Share Company, and Meta Abo Brewery.

\subsection{Data Source and Scope}

This study was limited to three ISO certified brewery companies in Ethiopia, namely, BGI Ethiopia, Dashen Brewery Share Company, and Meta Abo Brewery. For the study purpose, 14 years sales data in birr and quantity, cost of production data and profit data that cover from the year 2002 to 2015 were included. The financial report is collected from companies annual financial report document, companies website as well as central statistical agency of Ethiopia. The data includes financial business surveys of the companies before ISO registration and after ISO certification.

\subsection{Model Specification}

In this study fixed effect and random effect models were specified and Hausman test is done to develop final appropriate model.

\subsubsection{Fixed Effects Model}

We use fixed-effects model whenever we are only interested in analyzing the impact of variables that vary over time. Fixed Effect explore the relationship between predictor and outcome variables within an entity (country, person, company, etc.). Each entity has its own individual characteristics that may or may not influence the predictor variables (for example, the business practices of a company may influence its stock price).

Following Bartels and Brandom (2008) the fixed effect model is specified:

$\mathrm{Y}_{\mathrm{it}}=\beta 1 \mathrm{X}_{\mathrm{it}}+\alpha_{\mathrm{i}}+\mathrm{u}_{\mathrm{it}} \ldots \ldots \ldots \ldots \ldots . .$. Equation(1)

Where- $\alpha_{i}(i=1 \ldots n)$ is the unknown intercept for each company (company specific intercepts).

$Y_{\text {it }}$ is the dependent variable where $i=$ company and $t=$ time. $X_{\text {it }}$ represents one independent variable (IV), $\beta 1$ is the coefficient for that Independent Variable, $\mathrm{u}_{\mathrm{it}}$ is the error term.

By using binary variables the equation for the fixed effects model becomes:

Yit $=\beta_{0}+\beta_{1} X_{1 \text { it }}+\ldots+\beta_{k} X_{k i t}+\gamma_{2} E_{2}+\ldots+\gamma_{n} E_{n}+u_{\text {it }}-----------E q u a t i o n(2)$

Where $Y_{i t}$ is the dependent variable where $i=$ entity and $t=$ time. $X_{\text {kit }}$ represents independent variables, $\beta_{k}$ is the coefficient for the independent variables, $\mathrm{u}_{\mathrm{it}}$ is the error term, $\mathrm{E}_{\mathrm{n}}$ is the entity $\mathrm{n}$. Since they are binary (dummies) we have $n-1$ entities included in the model. $\gamma_{2}$ is the coefficient for the binary entities. Both equation(1) and equation(2)are equivalents: the slope coefficient on $\mathrm{X}$ is the same from one entity to the next.

\subsubsection{Random effect Model}

The justification of using random effects model is that, unlike the fixed effects model, the variation across company's is assumed to be random and uncorrelated with the predictor or independent variables included in the model. The important difference between fixed and random effects is whether the unobserved individual effect embodies elements that are correlated with the repressor's in the model, not whether these effects are stochastic or not(Green 2008, Oscar Torres-Reyna 2007). An advantage of random effects is that you can include time invariant variables .The model is specified as follows:

The random effects model is:

$\mathrm{Y}_{\mathrm{it}}=\alpha+\beta \mathrm{X}_{\mathrm{it}}+\mathrm{u}_{\mathrm{it}}+\varepsilon_{\mathrm{it}}----$ Equation(3)

In random-effects you need to specify those individual characteristics that may or may not influence the predictor variables. The difficulty with this is that some variables may not be existing therefore leading to omitted variable bias in the model.

\subsubsection{Choice of appropriate model}

To choice appropriate model either of fixed or random effects basic rule is running a Hausman test where the null hypothesis is that the preferred model is random effects against the alternative the fixed effects (Green 2008)as 
cited in Dejene,T. (2011) and Oscar Torres Reyna (2007, pp.29) . It basically tests whether the unique errors (ui) are correlated with the repressors, the null hypothesis is they are not.

After running a fixed effects and random effect model and saving the estimates, then Hausman test was performed. If the error terms are correlated, then Fixed Effect is no suitable since inferences may not be correct and you need to model that relationship (probably using random-effects), this is the main rationale for the Hausman test.

For analysis purpose the model was developed based on the above specification and work of Dejene,T. (2011), Levine and Toffel (2008) and Naser et al. (2004) by including major important explanatory variables.

The final model is:

PROFIT=f(SALES,REVENUE,COST)--------Equation(4)

To reduce the influence of outliers and to compensate for the difference in scale of measurement natural logarithm is preferred and specified as follows:-

$\operatorname{lnPROFIT} \mathrm{it}_{\mathrm{it}}=+\operatorname{lnSALES} \mathrm{it}+\mathrm{AVREV}_{\mathrm{it}}+\mathrm{AVCOST}_{\mathrm{it}}+\mathrm{DISO}_{\mathrm{it}}+\varepsilon_{\mathrm{it}}$----------Equation (5)

$$
\varepsilon_{\text {it }}=\mu_{\mathrm{i}}+v_{\mathrm{t}}
$$

Where, PROFIT is the company's profit which is used as a measure of performance. SALES represent the annual sales volume whereas AVREV and AVCOST denotes average revenue and average cost of production. ISO9001 is a dummy variable taking a value of one after the companies become ISO9001 certified and a value of zero before they were ISO9001 certified. The subscript i represents the cross-section(the companies) and t refers to time. Finally, $\varepsilon_{i t}$ is the error term composed of individual impact $\left(\mu_{i}\right)$ and time impact $\left(v_{t}\right)$ and "ln" is the natural logarithm of the variables. The joint significance of the coefficients is tested using the F-statistic. In addition, the overall explanatory power of the included repressors' is checked employing the R-square $\left(\mathrm{R}^{2}\right)$ value.

\subsection{Model Estimation Procedure}

The study employs three-phase procedural steps: pre-estimation, estimation and post estimation. The first step in the pre-estimation phase is the use of descriptive statistics in order to understand the nature of the data. The second step in this phase is the correlation matrix and variance inflation factor tests to check for the existence or otherwise of multicollinarity, hetrosckedasticity and correlation among the explanatory variables. The third step the Hausman test is applied to determine the appropriate estimator between fixed and random effect. At the end the appropriate model ( fixed effect model) is used to identify the impact of ISO9001 on companies performance.

\section{Empirical findings and discussions}

\subsection{Preliminary analyses}

The preliminary analyses are in three parts: descriptive statistics, inferential statistics and statistical significance test. STATA-14 statistical software package is employed for analysis.

\subsubsection{Descriptive Statistics}

The descriptive statistics of the major variables tells that the companies have jointly experienced a mean profit of 3869999185 birr and ranges between a minimum profit of 43,982,674 birr and a maximum profit of birr $1,139,824,452$.

Descriptive Statistics of Major Variables

\begin{tabular}{llll}
\hline \multicolumn{1}{c}{ Variables } & Minimum & Maximum & Mean \\
\hline Profit & $43,982,674$ & $1,139,824,452$ & 3869999185 \\
Sales & $11,600,660$ & $1,903,942,340$ & 604811509.3 \\
Average Revenue & 3.847179 & 30.97291 & 15.2 \\
Average Cost & 0.104628 & 18.93 & 9.897 \\
\hline
\end{tabular}

Source: our own calculation based on stata-14 output

The mean average revenue of three companies over the 14 years under consideration is 15.2 birr with a minimum value of 3.847179 birr and maximum value of 30.97291 birr. The mean average cost of companies is 9.897 birr with a minimum of 0.104628 and maximum of 18.96 . Finally, the companies sale volume has a mean of 604811509.3 litres with the minimum volume of 11600660litres and maximum volumes of 1,903,942,340litres sales.

Trends of companies sales, profit, average revenue and average cost in operation Descriptive statistics of companies operation before ISO certification

\begin{tabular}{llll}
\hline Variables & Mean & Maximum & minimum \\
\hline Profit & 1692167452 & 350385157 & 292994091 \\
Sales & 407219033 & 458886962 & 384769775 \\
Average Revenue & 29.89043 & 20.3 & 3.45 \\
Average Cost & 39.91386 & 18.9 & 8.2 \\
\hline
\end{tabular}


The above table shows the companies operational activities before taking ISO certification. The companies jointly have an average profit of 1692167452 birr with the maximum value of 350385157 birr and minimum value of $292994091 \mathrm{birr}$. They also have an average sale of 407219033 litres of beer with maximum of 458886962 litres of beer and minimum of 384769775 litres of beer .The companies have a mean of 9.38301 birr of average revenue with maximum of 16.86birr and minimum of 3.847 birr. Their mean average cost shows 39.91386birr with maximum of 18.9 birr and minimum of 8.2 birr.

Descriptive statistics of companies operation After ISO certification

\begin{tabular}{llll}
\hline Variables & Mean & Maximum & minimum \\
\hline Profit & 1426541715 & 3112135860 & 1426541715 \\
Sales & 2887097808 & 4997892644 & 2887097808 \\
Average Revenue & 23.41 & 67.545 & 23.41 \\
Average Cost & 24.09303 & 13.8 & 24.09303 \\
\hline
\end{tabular}

Source: our own computation based stata-14 output

The table indicates the companies operational activities after companies takes ISO certification. The companies jointly have an average profit of 1426541715 birr with the maximum value of $3112135860 \mathrm{birr}$ and minimum value of 1183216492 birr. They also have an average sale of 2887097808litres of beer with maximum of 4997892644 litres of beer and minimum of 1348740269litres of beer. The companies have a mean of 23.41birr of average revenue with maximum of 67.545birr and minimum of 16.96birr. Their mean average cost shows 24.09303 birr with maximum of 13.8 birr and minimum of $0.104628 \mathrm{birr}$.

Mean difference of companies before ISO9001 certification less after ISO9001certification

\begin{tabular}{llll}
\hline Variables & Mean before ISO19001 & Mean after ISO19001 & Mean difference \\
\hline Profit & 1692167452 & 1426541715 & $1,363,465,533$ \\
Total sale & 407219033 & 2887097808 & 2479878774 \\
Average Revenue & 29.89043 & 54.7184 & 24.82797 \\
Average cost & 39.91386 & 24.09303 & -15.8208 \\
\hline
\end{tabular}

\section{Source: Our own computation based on stata-14 output.}

When we compare the mean of these companies with respect to the time before ISO9001 certification and after ISO9001 certification, we can see that there is a significant change on the profit side of the companies. The mean difference of the profit of the companies was birr 1,363,465,533birr. This indicates that the impact of ISO9001 certification is visible on improving the profit that each company generate. This in indirectly shows that as the company's profit increase their performance also increases which could be described in terms of financial performance.

In addition to this improvement, the mean sales difference of companies was increased by 2479878774 units when compared to the time before ISO 9001 certification, which could indicate that an increase in the companies selling volume increases their profit. There is also a significant reduction in average cost of the companies before certification of ISO 9001 by 15.8208 which enables them to increase their profitability.

Diagram.1 Distribution of total sales of three companies over the period 2002-2015

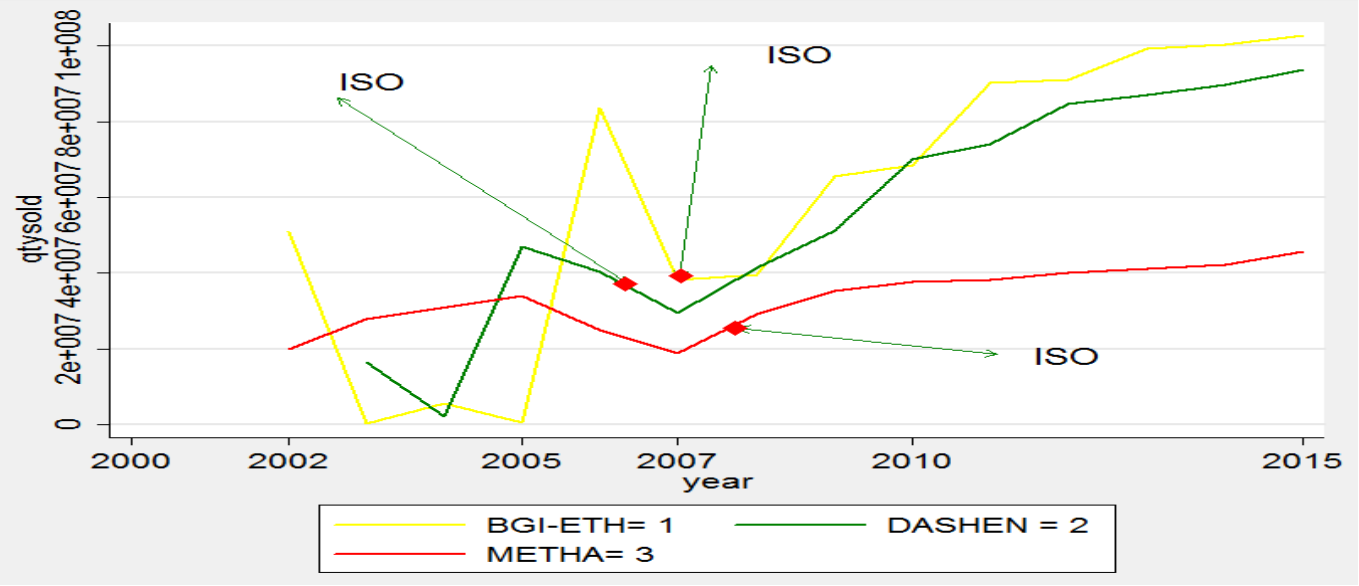

Source:stata-14 output

The company's sales trend before ISO certification shows a a great fluctuation however, after ISO9001 the company's sales trend shows an increasing rate with stability. This is mainly due to the reason that companies could have an access to foreign markets and the customers willingness to consume the same brand. Thus, these lead the company to perform better. Moreover, as the sales amount of the companies increased at alarming rate, the companies profit also boost at the rate that can support for the overall companies asset level. 


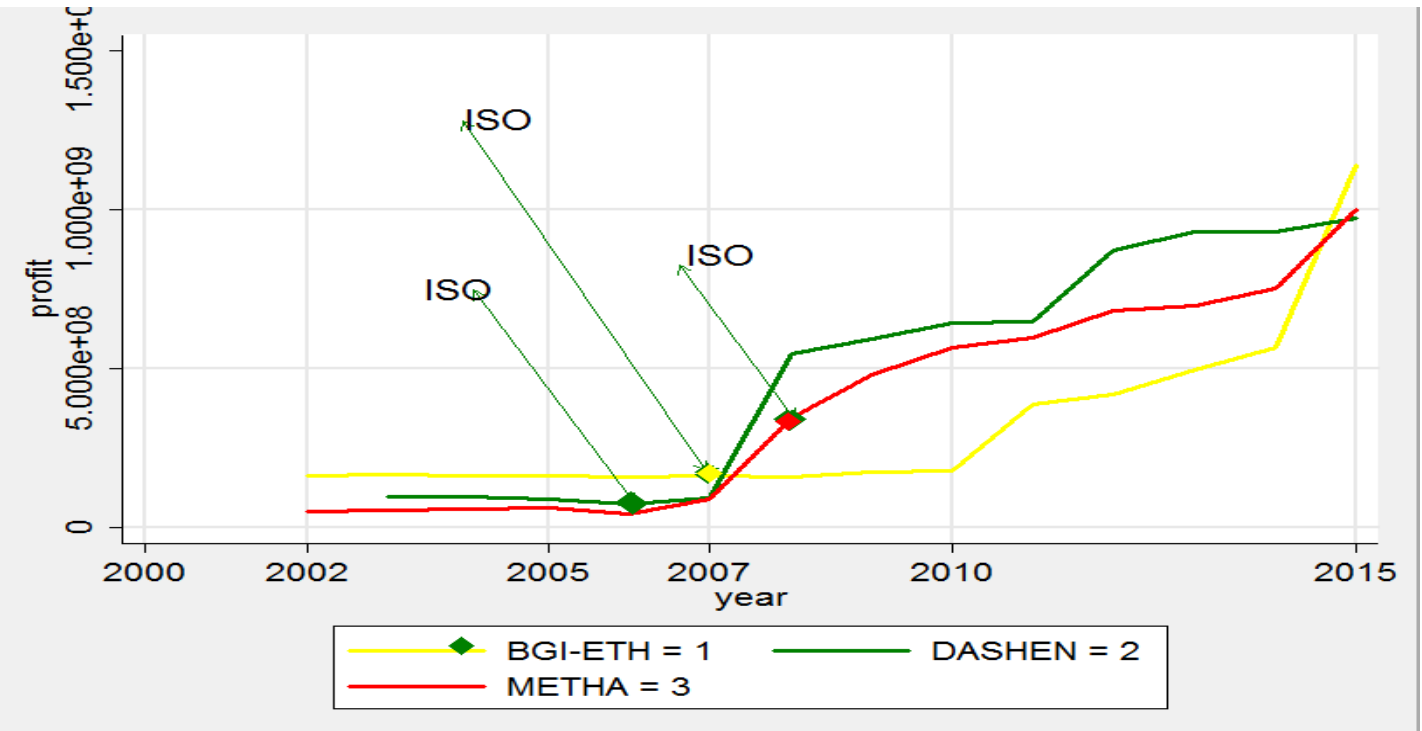

Diagram.2 Distribution of total profits of three companies over the period 2002-2015

\section{Source:Stata-14 output}

The trend on above diagrammatical presentation shows the profits of companies before ISO9001certification has indicates slight increase, but later after the companies certified trend of the company's performance have boosted at an increasing rate than before. Thus, we can state that ISO certification has a positive impact on this company's performance.

Diagram.3.Distribution of average revenue of three companies over the period 2002-2015

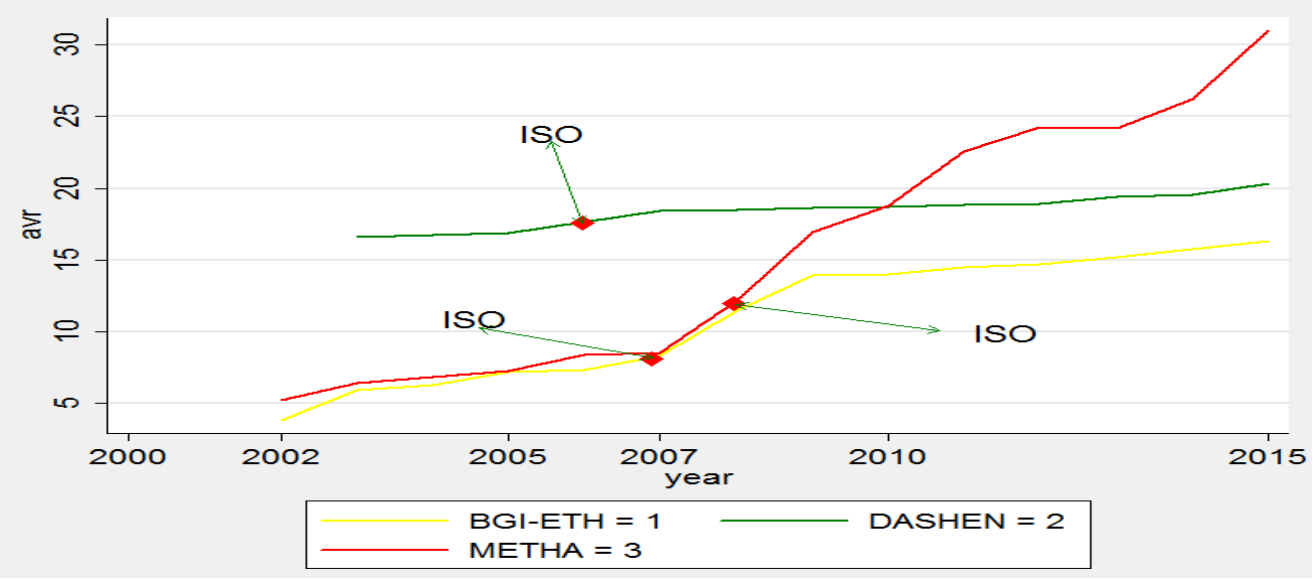

\section{Source:stata-14 output}

The diagram indicates the average revenues of three companies increased over the period after companies certified with ISO9001. This an increase in average revenue of brewery companies leads to their profitability.

Diagram.4 Distribution of average cost of three companies over the period 2002-2015

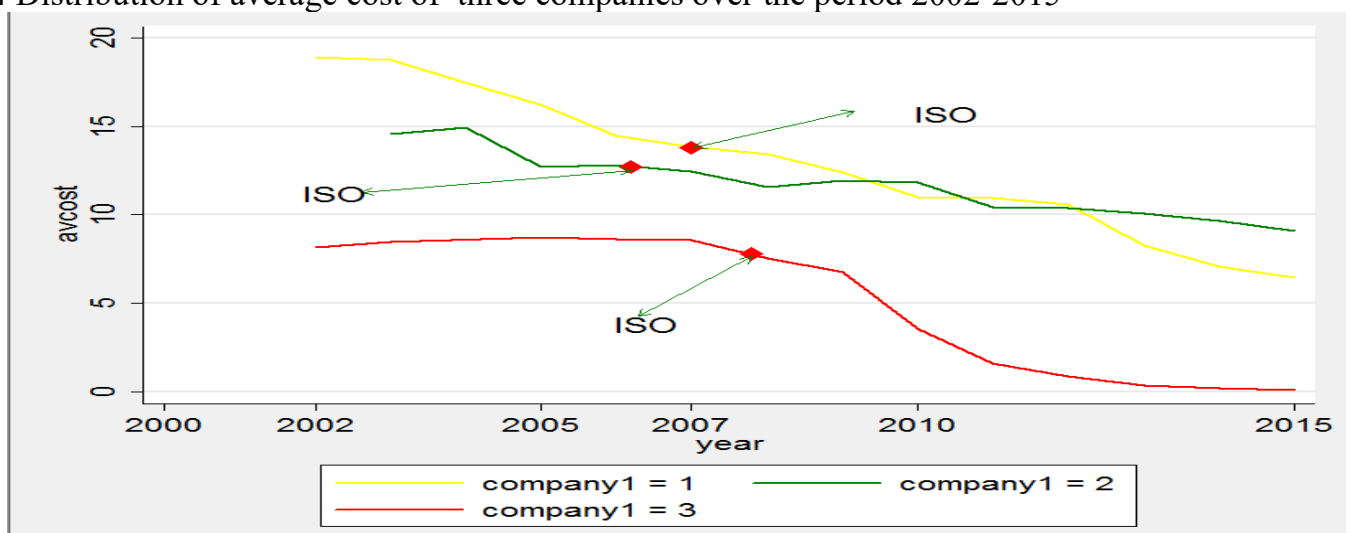

Source:stata-14 output

The trends of companies average cost over the period under consideration shows that the companies average 
cost decreased. Specially after the period of ISO9001 certification there is a significant decrease of average cost. This indirectly indicates that the ISO9001have a greater contribution in increasing the companies efficiency that enables them to reduce their average cost.

\subsection{Estimation results}

\subsubsection{Post estimation results}

In order to confirm the robustness of the estimated model, some diagnostic tests were conducted. The results of the omitted variable, heteroscedasticity, cross-sectional dependence and autocorrelation test are presented in turns. 4.3.2. Hetroscedasticity test

To apply Ordinary Least Square estimation in panel data model, existence of constant variance is an underlying assumption. As a result, to test the assumption of homoscedasticity in the panel data we used the usual BreuschPagan test.

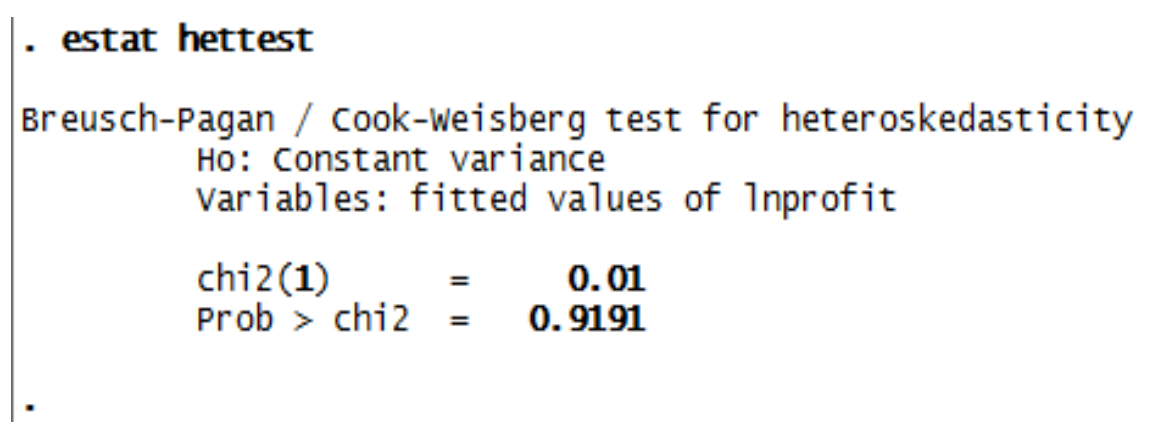

Source: regression result from Stata-14

As the Breuch-pagan test result above shows, the probability value of the chi-squared statistics is 0.9191 which indicates that the null hypothesis of constant-variance cannot be rejected means that there is no hetroscedasticity problem in the model. Therefore, the basic assumption of homoscedasticity is satisfied.

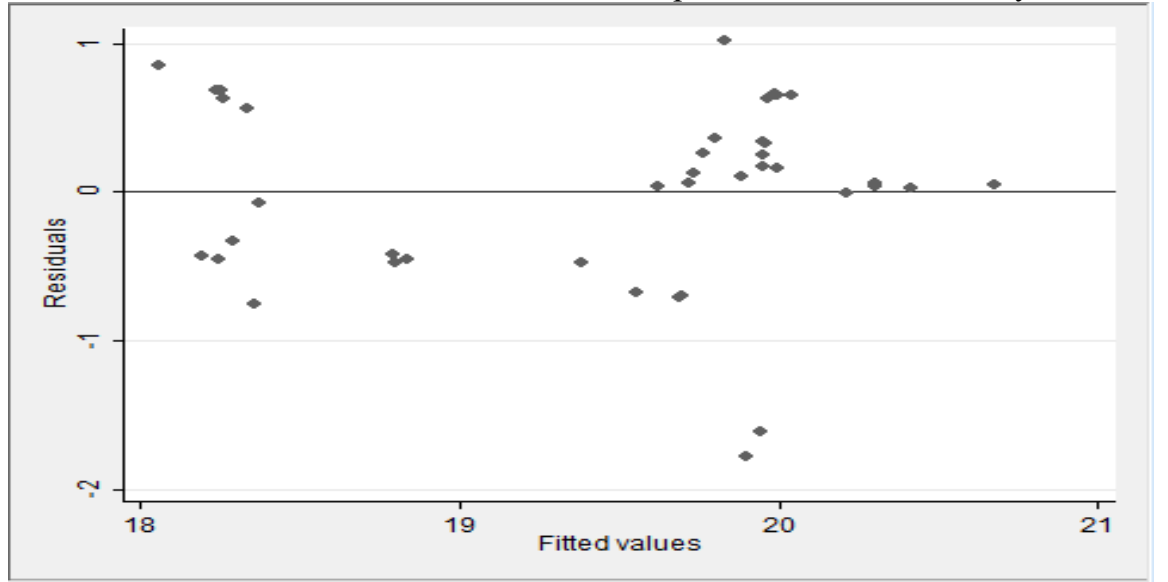

Source:stata-14 output

As the figure above shows there is no pattern which shows the existance of different varience between error terms, this indicates that there is a constant variance between error terms .

\subsubsection{Multicollinearity test}

To check whether there is severe multicollinearity in the model, the simple correlation coefficients between the explanatory variables have been examined.

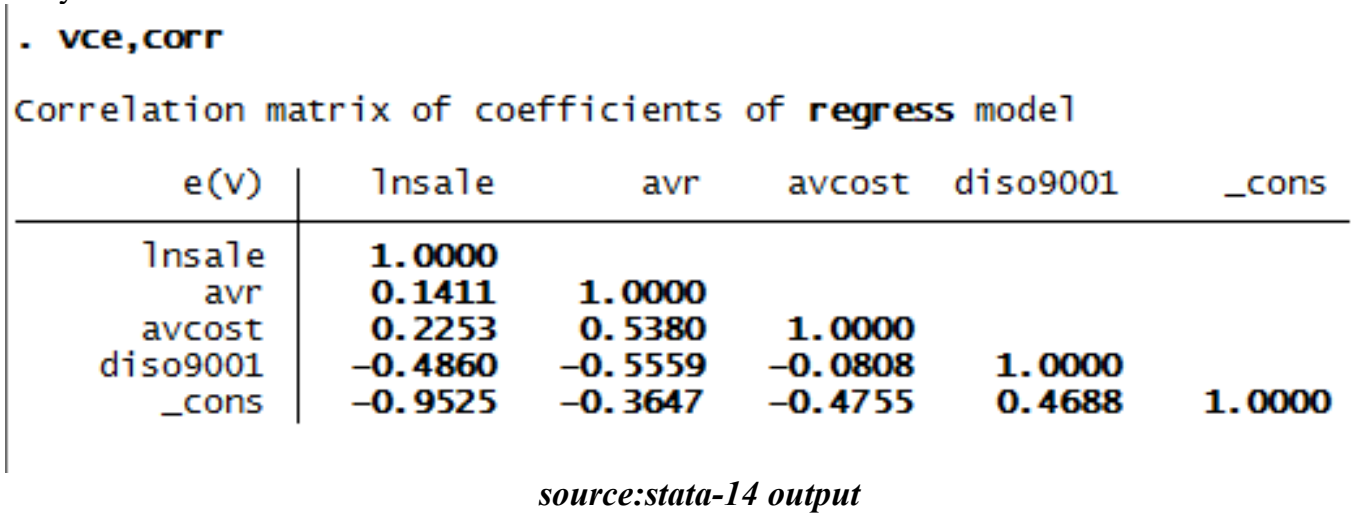


The test result above shows the values of all the correlation coefficients between the explanatory variables are lower than 0.53 which implies that the test does not discover the existence of severe multicollinearity of explanatory variables in the model.

In addition the problem of multicollinearity is tested using VIF(variance inflator factor).

\begin{tabular}{|r|rr}
\multicolumn{1}{l}{ vif } & & \\
variable & VIF & $1 /$ VIF \\
\hline avr & $\mathbf{2 . 6 4}$ & $\mathbf{0 . 3 7 9 0 3 5}$ \\
diso9001 & $\mathbf{2 . 4 6}$ & $\mathbf{0 . 4 0 7 1 6 4}$ \\
avcost & $\mathbf{1 . 8 6}$ & $\mathbf{0 . 5 3 7 0 9 0}$ \\
1nsale & $\mathbf{1 . 6 2}$ & $\mathbf{0 . 6 1 9 1 2 9}$ \\
\hline Mean vIF & $\mathbf{2 . 1 4}$ & \\
& &
\end{tabular}

\section{Source:stata-14 output}

According to the rule of thumb the explanatory variable VIF value of greater than 10 is responsible for problem of multicollinearity. The above VIF test result revealed that the maximum value of VIF of explanatory variable is 2.64 much more less than 10 indicates that there is no problem of multicollinearity.

\subsubsection{Regression result discussion}

After the classical leaner regression model assumptions were tested we analyze the impact of ISO9001 registration on the performance of the companies under consideration, the OLS estimation method is applied to the panel data. The estimation result of the panel data model is shown below.

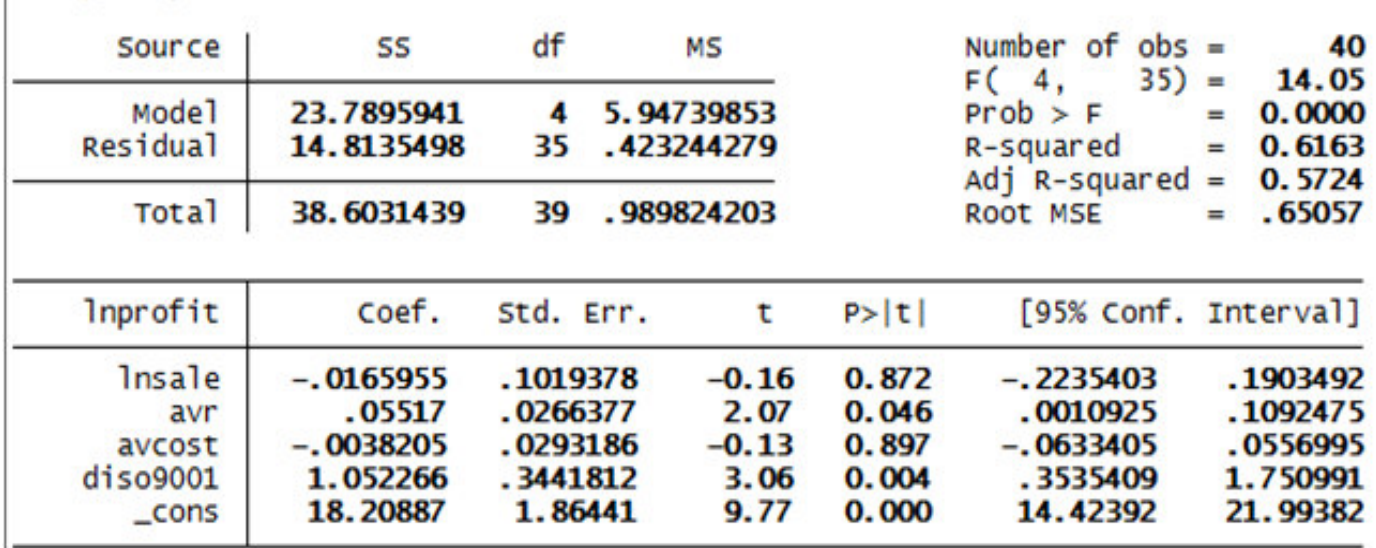

\section{Source:stata-14 output}

By using significant variables the estimated model become:-

\section{LnPROFIT $=18.20887+0.05517 \boldsymbol{A}$ VR +1.052266 DISO9001}

The model is good fit because the p-value $(0.000)$ is significant at $1 \%$ level and $\mathrm{R}^{2}(61.6 \%)$ indicates that $61.6 \%$ of the variation in natural logarithm of profit is explained by the included independent variables in the model such as sales volume, average price, ISO9001 certification, and average cost., and $39.4 \%$ of variation in dependent variable(LnProfit) is not explained because of an excluded explanatory variables. The joint significance test for the null hypothesis that all coefficients of the explanatory variables are jointly equal to zero is rejected at one percent significance level. The output above reveals that ISO9001 certification and average revenue have a significant impact on profit of the companies while average cost and sales volume appeared to be insignificant.

The regression result indicated that ISO9001 certification $(p$-value $=0.004)$ has a positive and significant impact at one percent level of significance indicating that the certification positively affects the company's profit. The company's profit increases by $1.052 \%$ percent due to ISO9001 certification. This result is consistent with the study done by Dejene,T. (2011) on five brewery companies in Ethiopia and other scholars like Sharma (2005), Pinar (2001), singles et al.(2000) but, inconsistent with the finding of Vander Wiele et al.(2000) .

Average revenue(avr) variable is found to be significant ( $\mathrm{p}$-value=0.046)at $5 \%$ level of significance with positive coefficient. That is, a one percent increase (decrease) in average revenue of companies results in a 5.517 percent increase (decrease) in the company's profit. The result is in line with the theory that an increase in the price of a product improves the profit of a company while the decrease in per unit price obviously reduces the profit, provided that the costs are not changing in identical proportion.

The estimated coefficient of annual total sales(lnsale) is negative and insignificant (even at ten percent level of significance). This fails to support the principle that more sales increase the profit of a company while reduction in sales results in reduced profit. Similarly, average per unit cost(avcost) is found to be insignificant with negative sign. This result also fails to support the assumption that says the reduction in production cost fosters the 
profitability of companies.

\section{Conclusions}

In a production systems Performance can be measured in terms of Quality-based measure, Time-based measure, Cost- based measure or Flexibility based measures. Among these performance measurements, financial performance measure which is cost based measurement is used to evaluate the impact of ISO9001 on performance of brewery companies. The panel data of three companies for 14 years starting from 2002 up to 2015 was used for analysis purpose. For empirical analysis of the panel data to select appropriate model hausman-test was carried and fixed effect econometric model is employed to analyze the data.

The study finding indicates that there is a strong positive relation between ISO9001 certification and companies performance. The results indicate that ISO certification affects the company's performance in different dimension of performance indicators. ISO certification has improved the individual companies profit from time to time especially after they are certified when compared with their state of performance before the certificate.

The study result indicates that ISO9001 certification( $\mathrm{p}$-value $=0.004$ ) has a positive and significant impact at one percent level of significance indicating that the certification positively affects the company's profit. The company's profit increases by $1.052 \%$ percent due to ISO 9001 certification. In addition to this annual average revenue do have a significant impact on the company's performance. Whereas average cost and volume of sale has no significant impact on companies performance.

This result is consistent with the study done by Dejene,T. (2011) on five brewery companies in Ethiopia and other scholars like Sharma (2005), Pinar (2001),singles et al.(2000) but, inconsistent with the finding of Vander Wiele et al.(2000)

Another indicator of the company's performance is their annual average revenue of each company plays a significant role in determining their performance. The regression result shows, a one percent increase (decrease) in average revenue of companies results in a 5.517 percent increase (decrease) in the company's profit.

In general, as ISO9001 certification is not the only goal of any company, the companies should consider more than a few internal factors that can contribute to the company's profitability. The company should consider the employee side contribution to the performance of the company. They should also search for other ways of performing well in their industry and in the international markets. Brewery companies needs to Improve their production capacity to level of their available potential.

\section{References}

(No Date) Available at: http://www.diageo.com/en-ie/Investor/pages/resource (Accessed: 29 December 2016).

(No Date) Available at: http://www.wsj.com/.../heineken-to-open-new-brewery-in-ethiopia-1403276971 (Accessed: 29 December 2016).

2016, D. (2016) Home. Available at: http://www.diageo.com (Accessed: 29 December 2016).

Brandon L. Bartels (2008). Beyond fixed versus random effects: A framework for improving substantive and statistical analysis of panel, time-Series cross-sectional, and multilevel data

Cagnazzo,L., Taticchi,P. and Fuiano,F,. (2009), Impacts of ISO 9001 on Business Performance:A Literature Review, www.wseas.us/e library/conferences/2009/tenerife/.../EACT-ISP-05.

Capistrano, Erik Paolo S. . (2008). ISO 9001 Certification and Business Performance of Selected Philippine Companies. Philippine Management Review. 15(1), pp. 15-36.

Corbett, Charles J., Montes, María J., Kirsch, David A. and Alvarez-Gil María J. (2002), Does ISO 9001 certification pay? ISO Management Systems - July-August 2002

Davis L.. (1997), Quality Assurance: ISO 9001 as a Management Tool, Copenhagen: Copenhagen Business School Press.

Davis, L. (1997) Quality Assurance: ISO 9001 as a Management Tool. Copenhagen: Copenhagen Business School Press.

Dejene ,T.. (2011). Impact of ISO9001 certification on companies performance-The case of Ethiopian brewery companies. Master of Business Administration Thesis, Addis Ababa University Graduate studies.

Dimara, E., Skuras, D., Tsekouras, K. and Goutsos, S.. (2004). International Quality \& Reliability Management. International Journal . 12(3) , pp. 6-8.

Feng, M., Terziovski, M. and Samson, D. . (2008). Relationship of ISO 9001 quality system certification with operational and business performance: A survey in Australia and New Zealand-based manufacturing and service companies. Journal of Manufacturing Technology Management. 19(1), pp. 22-37.

Finch, Byron J.. (2003), Operations, Processes, Value, and Profitability, New York: USA

Gotzamani, Katerina, D. and Tsiotras, G.D.. (2002). The true motive behind ISO 9001 certification: Their impact on the overall certification benefits and long term contribution towards TQM. International Journal of Quality \& Reliability Management. . 19(2), pp. 151-169.

Harris, Douglas H. and Chaney, Frederick B. (1969), Human Factors in Quality Assurance, New York, London, 
Sydney, Toronto: JOHN WILEY \& SONS, INC.

Heinekeninternational (2016)in Wikipedia.Availableat:https://en.wikipedia.org/wiki/Heineken International (Accessed: 29 December 2016).

Heras, I., Dick, Gavin P.M. and Casadesu,M... (2002). ISO 9001 Registration's Impact on Sales and Profitability. A longitudinal analysis of performance before and after accreditation. International Journal of Quality \& Reliability Management. 19(1), pp. 774-791.

Jackson, P. and Ashton, D. (1995), Managing a Quality System Using BS/EN/ISO 9001 (formerly BS 5750). London, Great Britain: Kogan Page Ltd.

Johnson and Perry L.. (1993), ISO 9001: Meeting the New International Standards, New York: USA.

Kuo, T., Chang, T., Hung, K., and Lin, M. . (2009). Employees' perspective on the impactiveness of ISO 9001 certification: A Total Quality Management framework, Total Quality Management. International journal. 6(1), pp. 14-17.

Kuozi and Padibjo.. (2011). The effects of total quality management on financial performance of manufacturing companies in Kenya: case of East African Breweries Limited. Available at: http://etd-library.ku.ac.ke8080 (Accessed: 29 December 2016).

Levine and Toffel, M. W. (2008), Management and Job Quality: How the ISO 9001 Standard for Quality Management Systems Affects Employees and Employers, Berkeley: Institute for Research on Labor and Employment- Working Paper Series, University of California.

Masternak, T. Kleiner, and Brian, H. . (1995). ISO 9001 . what it means to international business today . Training for Quality. 3(1), pp. 15-18.

Mulili, Dennis M. (2011), The effects of total quality management on financial performance of manufacturing companies in Kenya: case of East African Breweries Limited, http://etd-library.ku.ac.ke8080.

Naser, K., Karbhari Y. and Mokhtar M. Z. . (2004). Impact of ISO 9001 registration on company performanceEvidence from Malaysia. Managerial Auditing Journal. 14(2), pp.13-16.

Oscar Torres-Reyna.2007.Panel data Analysis Fixed and Random Effects using stata0torres@princeton.ed.(online).Available at:http:/ss.princton.edu/training/.(accessed 4 Decmber 2006)

Padmadinata, Fatimah Zulfah S. (2007), Quality Management System and Product Certification Process and Practices for SME In Indonesia- A Paper presented at the National Workshop on Sub-national Innovation Systems and Technology Capacity Building Policies to Enhance Competitiveness of SMEs, organized by UN-ESCAP and Indonesian Institute of Sciences (LIPI), Jakarta, 3 - 4 April 2007.

Pinar, M., Pinar, M.C., and Crouch, H.L.. (2001). Do all companies achieve their expectations from ISO 9001 certification? An empirical study in Turkey. Journal of Global Awareness. 2(1), pp. 62-71.

Piskar, F. . (2007). The Impact of the Quality Management System ISO 9001 on Customer Quality \& Reliability Management. managerial auditing journal. 19(1), pp. 41-44.

Places (2016) Cycle brewing. Available at: https://www.facebook.com/Cycle-Brewing-454861824560821 (Accessed: 29 December 2016).

Ragothaman, S. and Korte, L. (1999), The ISO 9001 International Quality Registration: An Imperical Anlysis of Implications for Business Firms. International Journal of Applied Quality Management, Vol.2, N0. 1, pp. 5973

Santos L. and Escanciano C. . ( 2002). Benefits of the ISO 9001: Some considerations to reinforce competitive advantage. International Journal of Quality \& Reliability Management. 19(1), pp. 321-344.

Senior quality controller (2016) Available at: http://www.ethiojobs.net/company/.../Diageo-META-AboBrewery-S.C/ (Accessed: 29 December 2016).

Sharma, D. S. . (2005). The Association between ISO 9001 Certification and Financial Performance. International Journal of Accounting. 40(1), pp.151-172.

Singles, J., Ruel, G., and van de Water, H.. (2001). ISO 9001 Series Certification and Performance. International Journal of Quality and reliability Management. 18(1), pp. 62-75.

Terlaak, A. and King, Andrew A. . (2006). The Impact of Certification With The ISO 9001 Quality Management Standard: A Signaling Approach,. Journal of Economic Behavior \& Organization . 60(1), pp. 579-602.

Tumamala and Tangle H.. (1997), Quality Management and Competitiveness: The Diffusion of The ISO 9001 Standards in Latin America and Recommendations for Government Strategies United Nations, Division of Production, Productivity and Management, Santiago: Chile.

User,S.(no-date) Dashen-brewery.Availableat: http://www.tiretinvestment.com.et/index.php/companies/dashenbrewery(Accessed:29 December 2016).

Van Der Wiele, A., Dale, B. G. and Williams, A.R.T. . (2000). ISO 9001 Series and Excellence Models: Fad to Fashion to Fit.Journal of General Management. 25(2), pp.12-19.

Wu and Liu S. (2010). The Performance Measurement Perspectives and Causal Relationship for ISO-certified companies: a case of electronic industry. International Journal of Quality \& Reliability Management. 27(1), pp.27-47. 


\section{Notes}

Note 1: BGI-ETHIOPIA brewery company

\begin{tabular}{|l|l|l|l|l|l|}
\hline year & Total Cost & Quantity produced & Quantity sold & Total Sole & Profit \\
\hline 2002 & 34139541 & 36707410 & $51,042,514$ & $196,369,680$ & $162,230,139$ \\
\hline 2003 & $32,108,862$ & 370010 & 368,225 & $198,810,702$ & $166,701,840$ \\
\hline 2004 & 39807515 & 86578188 & $5,457,637$ & $203,706,862$ & $163,899,347$ \\
\hline 2005 & 44251246 & 380765 & 378,526 & $204,857,952$ & $160,606,706$ \\
\hline 2006 & 40482294 & 83581997 & $83,684,976$ & $199,155,184$ & $158,672,890$ \\
\hline 2007 & 43668284 & 38669722 & $38,340,529$ & $205,271,596$ & $161,603,312$ \\
\hline 2008 & 19750420 & 45637882 & $39,436,278$ & $176,617,668$ & $156,867,248$ \\
\hline 2009 & 151129412 & 361480567 & 65480515 & 324322450.5 & $173,193,039$ \\
\hline 2010 & 223082534 & 7768448639 & 68479349 & $400,532,293$ & $177,449,759$ \\
\hline 2011 & 290988494 & 2133307189 & $90,323,114$ & $678,852,601$ & $387,864,107$ \\
\hline 2012 & 310898449 & 541306189 & $91,201,113$ & $729,072,738$ & $418,174,289$ \\
\hline 2013 & 317895520 & 1221310357 & $99,224,240$ & $813,188,160$ & $495,292,640$ \\
\hline 2014 & 410991345 & 5473244011 & $100,431,540$ & $978,031,170$ & $567,039,825$ \\
\hline 2015 & 540125332 & $1,239,065,734$ & $102,769,098$ & $1,679,949,784$ & $1,139,824,452$ \\
\hline
\end{tabular}

Note 2: DASHEN BREWERY COMPANY

\begin{tabular}{|c|c|c|c|c|c|}
\hline year & Total Cost & Quantity produced & Quantity sold & Total Sole & Profit \\
\hline 2002 & 41074090 & 55413797 & $23 \quad: 8$ & 136832431 & 95758341 \\
\hline 2003 & 41180321 & 26112895 & $16533 y \overline{70}$ & 136832432 & 95652111 \\
\hline 2004 & 31540056 & 252451 & 2151862 & 127318775 & 95778719 \\
\hline 2005 & 34684316 & 48825739 & 46979884 & 125022843 & 90338527 \\
\hline 2006 & 32754412 & 41309083 & 40409078 & 106626771 & 73872359 \\
\hline 2007 & 39090479 & 27287720 & 29486373 & 130054934 & 90964455 \\
\hline 2008 & 23717772 & 41431430 & 41359834 & 571556874 & 547839102 \\
\hline 2009 & 280169996 & 7736287 & 51333119 & 873870060 & 593700064 \\
\hline 2010 & $555,180,006$ & $81,195,067$ & $70,036,772$ & $1,199,998,428$ & $644,818,422$ \\
\hline 2011 & $650,595,290$ & $102,654,923$ & $73,989,997$ & $1,298,421,292$ & $647,826,002$ \\
\hline 2012 & $687,593,562$ & $127,768,139$ & $84,648,710$ & $1,561,290,134$ & 873696572 \\
\hline 2013 & $701,283,221$ & $137,542,107$ & $87,082,453$ & $1,632,100,342$ & $930,817,121$ \\
\hline 2014 & $820,320,345$ & $145,009,324$ & $89,678,093$ & $1,751,893,001$ & $931,572,656$ \\
\hline 2015 & $932,110,352$ & $153,218,320$ & $93,675,812$ & $1,903,942,340$ & $971,831,988$ \\
\hline
\end{tabular}

Note 3: METHA-ABO BREWERY COMPANY

\begin{tabular}{|l|l|l|l|l|l|}
\hline year & Total Cost & Quantity produced & Quantity sold & Total Sole & Profit \\
\hline 2002 & 13612024 & 11594969 & $19,899,573$ & $65,147,552$ & $51,535,528$ \\
\hline 2003 & $13,926,508$ & 30601797 & $27,885,143$ & $66,924,343$ & $52,997,835$ \\
\hline 2004 & 12127585 & 27957369 & $26,666,932$ & $63,377,252$ & $51,249,667$ \\
\hline 2005 & 15165167 & 34529778 & $34,086,287$ & $78,556,609$ & $63,391,442$ \\
\hline 2006 & 15638994 & 24843376 & $25,064,609$ & $59,621,668$ & $43,982,674$ \\
\hline 2007 & 29271621 & 18732350 & $18,718,734$ & $117,196,597$ & $87,924,976$ \\
\hline 2008 & 11600660 & 272558 & $29,236,750$ & $355,648,494$ & $344,047,834$ \\
\hline 2009 & 122055622 & 307622 & $35,392,254$ & $600,565,727.50$ & $478,510,106$ \\
\hline 2010 & 141938218 & 319,997 & 37713605 & $707,264,990$ & $565,326,772$ \\
\hline 2011 & $262,544,414$ & $26,354,568$ & $38,099,998$ & $859,109,762$ & $596,565,348$ \\
\hline 2012 & $285,679,220$ & $31,095,542$ & $39,980,475$ & $968,094,356$ & $682,415,136$ \\
\hline 2013 & $301,210,119$ & $35,193,892$ & $41,240,509$ & $997,340,300$ & $696,130,181$ \\
\hline 2014 & $357,025,209$ & $38,891,109$ & $42,310,601$ & $1,109,547,231$ & $752,522,022$ \\
\hline 2015 & $413,521,100$ & $41,750,291$ & $45,652,819$ & $1,414,000,520$ & $1,000,479,420$ \\
\hline
\end{tabular}


Note 4: Data in Stata14

\begin{tabular}{|c|c|c|c|c|c|c|c|c|c|c|}
\hline & company & year & profit & 1 nprofit & qtysold & Insale & avr & $\operatorname{avcos} t$ & dis09001 & company 1 \\
\hline 1 & BGI-ETH & 2002 & $1.622 \mathrm{e}+08$ & 18.90453 & 51042514 & 17.74817 & 3.847179 & 18.93004 & 0 & 1 \\
\hline 2 & BGI-ETH & 2003 & $1.667 \mathrm{e}+08$ & 18.93172 & 368225 & 12.81645 & 5.916361 & 18.77836 & 0 & 1 \\
\hline 3 & BGI-ETH & 2004 & $1.639 \mathrm{e}+08$ & 18.91476 & 5457637 & 15.51253 & 6.325103 & 17.45979 & 0 & 1 \\
\hline 4 & BGI-ETH & 2005 & $1.606 \mathrm{e}+08$ & 18.89447 & 378526 & 12.84404 & 7.199157 & 16.21668 & 0 & 1 \\
\hline 5 & BGI-ETH & 2006 & $1.587 e+08$ & 18.88235 & 83684976 & 18.24257 & 7.37982 & 14.48434 & 0 & 1 \\
\hline 6 & BGI-ETH & 2007 & $1.616 \mathrm{e}+08$ & 18.90066 & 38340529 & 17.46202 & 8.353907 & 13.82926 & 1 & 1 \\
\hline 7 & BGI-ETH & 2008 & $1.569 \mathrm{e}+08$ & 18.87091 & 39436278 & 17.4902 & 11.47856 & 13.43276 & 1 & 1 \\
\hline 8 & BGI-ETH & 2009 & $1.732 \mathrm{e}+08$ & 18.96992 & 65480515 & 17.99726 & 13.95296 & 12.41808 & 1 & 1 \\
\hline 9 & BGI-ETH & 2010 & $1.774 \mathrm{e}+08$ & 18.9942 & 68479349 & 18.04204 & 14.0095 & 11.02872 & 1 & 1 \\
\hline 10 & BGI-ETH & 2011 & $3.879 e+08$ & 19.77617 & 90323114 & 18.3189 & 14.51582 & 10.9364 & 1 & 1 \\
\hline 11 & BGI-ETH & 2012 & $4.182 e+08$ & 19.85141 & 91201113 & 18.32858 & 14.74121 & 10.57435 & 1 & 1 \\
\hline 12 & BGI-ETH & 2013 & 4. $953 e+08$ & 20.02066 & 99224240 & 18.41289 & 15.19546 & 8.26029 & 1 & 1 \\
\hline 13 & BGI-ETH & 2014 & $5.670 e+08$ & 20.15594 & 100431540 & 18.42499 & 15.73829 & 7.075091 & 1 & 1 \\
\hline 14 & BGI-ETH & 2015 & $1.140 e+09$ & 20.85414 & 102769098 & 18.448 & 16.34684 & 6.435914 & 1 & 1 \\
\hline 15 & DASHEN & 2003 & 95652111 & 18.37623 & 16533970 & 16.62093 & 16.57584 & 14.57701 & 0 & 2 \\
\hline 16 & DASHEN & 2004 & 95778719 & 18.37755 & 2151862 & 14.58184 & 16.71668 & 14.93536 & 0 & 2 \\
\hline 17 & DASHEN & 2005 & 90338527 & 18.31907 & 46979884 & 17.66523 & 16.8612 & 12.71037 & 0 & 2 \\
\hline 18 & DASHEN & 2006 & 73872359 & 18.11785 & 40409078 & 17.51456 & 17.63868 & 12.79291 & 1 & 2 \\
\hline 19 & DASHEN & 2007 & 90964455 & 18.32598 & 29486373 & 17.19944 & 18.41068 & 12.43253 & 1 & 2 \\
\hline 20 & DASHEN & 2008 & $5.478 \mathrm{e}+08$ & 20.12149 & 41359834 & 17.53782 & 18.51913 & 11.57246 & 1 & 2 \\
\hline 21 & DASHEN & 2009 & $5.937 e+08$ & 20.20189 & 51333119 & 17.75385 & 18.62351 & 11.91505 & 1 & 2 \\
\hline 22 & DASHEN & 2010 & $6.448 \mathrm{e}+08$ & 20.28448 & 70036772 & 18.06453 & 18.73383 & 11.83761 & 1 & 2 \\
\hline 23 & DASHEN & 2011 & $6.478 \mathrm{e}+08$ & 20.28913 & 73989997 & 18.11944 & 18.84861 & 10.43769 & 1 & 2 \\
\hline 24 & DASHEN & 2012 & $8.737 e+08$ & 20.58824 & 84648710 & 18.25402 & 18.94435 & 10.38157 & 1 & 2 \\
\hline 25 & DASHEN & 2013 & $9.308 \mathrm{e}+08$ & 20.65157 & 87082453 & 18.28237 & 19.42012 & 10.09868 & 1 & 2 \\
\hline 26 & DASHEN & 2014 & $9.316 \mathrm{e}+08$ & 20.65238 & 89678093 & 18.31174 & 19.53535 & 9.657018 & 1 & 2 \\
\hline 27 & DASHEN & 2015 & $9.718 \mathrm{e}+08$ & 20.69469 & 93675812 & 18.35535 & 20.3248 & 9.083544 & 1 & 2 \\
\hline 28 & METHA & 2002 & 51535528 & 17.75778 & 19899573 & 16.80621 & 5.273817 & 8.17396 & $\circ$ & 3 \\
\hline 28 & METHA & 2002 & 51535528 & 17.75778 & 19899573 & 16.80621 & 5.273817 & 8.17396 & 0 & 3 \\
\hline 29 & METHA & 2003 & 52997835 & 17.78576 & 27885143 & 17.1436 & 6.4 & 8.455088 & 0 & 3 \\
\hline 30 & METHA & 2005 & 63391442 & 17.96484 & 34086287 & 17.34441 & 7.30464 & 8.739191 & 0 & 3 \\
\hline 31 & METHA & 2006 & 43982674 & 17.59931 & 25064609 & 17.03697 & 8.378719 & 8.629503 & 0 & 3 \\
\hline 32 & METHA & 2007 & 87924976 & 18.29199 & 18718734 & 16.74504 & 8.560925 & 8.562624 & 0 & 3 \\
\hline 33 & METHA & 2008 & $3.440 \mathrm{e}+08$ & 19.65629 & 29236750 & 17.19094 & 12.16443 & 7.56217 & 1 & 3 \\
\hline 34 & METHA & 2009 & $4.785 e+08$ & 19.98619 & 35392254 & 17.382 & 16.96885 & 6.771434 & 1 & 3 \\
\hline 35 & METHA & 2010 & $5.653 e+08$ & 20.15291 & 37713605 & 17.44553 & 18.75358 & 3.56109 & 1 & 3 \\
\hline 36 & METHA & 2011 & $5.966 \mathrm{e}+08$ & 20.2067 & 38099998 & 17.45572 & 22.54881 & 1.620079 & 1 & 3 \\
\hline 37 & METHA & 2012 & $6.824 \mathrm{e}+08$ & 20.34115 & 39980475 & 17.5039 & 24.21418 & .8714393 & 1 & 3 \\
\hline 38 & METHA & 2013 & 6. $961 \mathrm{e}+08$ & 20.36105 & 41240509 & 17.53493 & 24.18351 & .3585908 & 1 & 3 \\
\hline 39 & METHA & 2014 & $7.525 \mathrm{e}+08$ & 20.43894 & 42310601 & 17.56055 & 26.22386 & .1801241 & 1 & 3 \\
\hline 40 & METHA & 2015 & $1.000 e+09$ & 20.72375 & 45652819 & 17.63658 & 30.97291 & .104628 & 1 & 3 \\
\hline
\end{tabular}

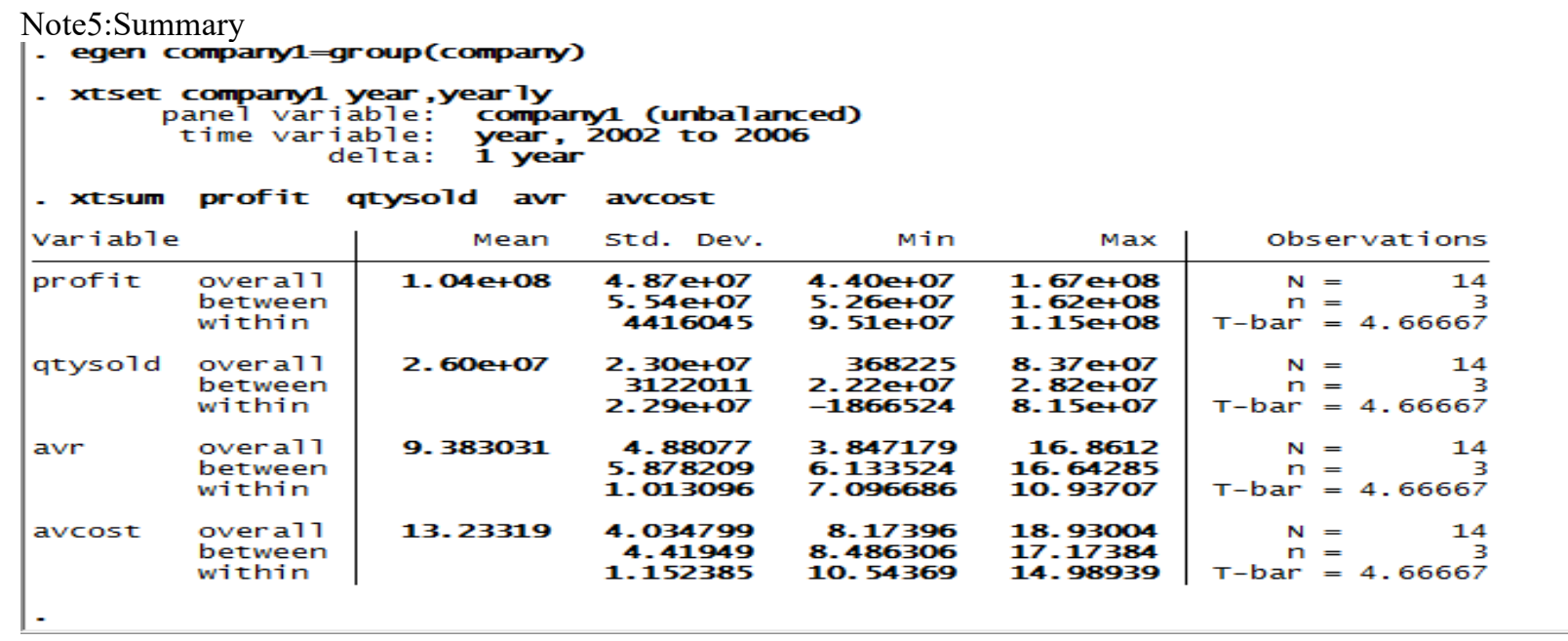

